\title{
Pengembangan Model Pembelajaran Pendidikan Agama Islam Dengan Pendekatan Simulasi
}

\author{
Eha Suhayati, Naylur Rosyid \\ STKIP Banten \\ Corresponding Author. Email: ehasuyati89@gmail.com
}

\begin{abstract}
This study aims to develop a learning model for Islamic religious education with a simulation approach in STKIP Banten. This research method uses research and development through 7 stages, namely research and data collection, needs analysis, development planning, expert evaluation, revision, user evaluation, development and revision. The experts involved in this study were material experts, instructional design experts, instructional media experts, while the test included one-on-one tests, small group tests and field tests. The instruments used to collect data were questionnaires and interviews. Ended with a test, an evaluation of the effectiveness of learning is carried out in the form of multiple choice tests (cognitive areas) and practice (psychomotor fields). The learning evaluation determines the competency standards that students must achieve after studying Islamic Education is 75 (seventy five). The results of this research data analysis can be concluded that the PAI learning model used is effective for students, because it can make it easier for students to understand competencies.
\end{abstract}

\begin{abstract}
Abstrak: Penelitian ini bertujuan untuk mengembangkan model pembelajaran pendidikan agama islam dengan pendekatan simulasi di STKIP Banten. Metode penelitian ini menggunakan penelitian dan pengembangan melalui 7 tahapan yaitu penelitian dan pengumpulan data, analisis kebutuhan, perencanaan pengembangan, evaluasi ahli, revisi, evaluasi pengguna, pengembangan dan revisi. Ahli yang terlibat dalam penelitian ini adalah ahli materi, ahli desain pembelajaran, ahli media pembelajaran, sedangkan tes meliputi tes satu-satu, tes kelompok kecil dan tes lapangan. Instrumen yang digunakan untuk mengumpulkan data adalah angket dan wawancara. Diakhiri dengan tes, dilakukan evaluasi tentang keefektifan pembelajaran berupa tes pilihan ganda (bidang kognitif) dan praktik (bidang psikomotorik). Evaluasi pembelajaran menentukan standar kompetensi yang harus dicapai siswa setelah mempelajari PAI adalah 75 (tujuh puluh lima). Hasil analisis data penelitian ini dapat disimpulkan bahwa model pembelajaran PAI yang digunakan efektif bagi siswa, karena dapat memudahkan siswa dalam memahami kompetensi.
\end{abstract}

\section{Key Words:}

Development, Learning

Model, Simulation.

Kata Kunci:

Pengembagan, Model

Pembelajaran, Simulasi.

How to Cite: Suhayati, E., \& Rosyid, N. (2020). Pengembangan Model Pembelajaran Pendidikan Agama Islam Dengan Pendekatan Simulasi. Jurnal Teknologi Pendidikan, 5(2), 116-125. Retrieved from http://ojs.ikipmataram.ac.id/index.php/jtp/article/view/3080

\section{Pendahuluan}

Pusat kurikulum Depdiknas (2003) mengemukakan bahwa pendidikan agama islam di Indonesia adalah bertujuan untuk menumbuhkan dan meningkatkan keimanan peserta didik melalui pemberian dan pemupukan pengetahuan, penghayatan, pengalaman serta pengalaman peserta didik tentang agama Islam sehingga menjadi manusia muslim yang terus berkembang dalam hal keimanan, ketakwan kepada Allah SWT, serta berakhlak mulia dalam kehidupan pribadi, bermasyarakat, berbangsa dan bernegara. Pendidikan agama Islam di samping bertujuan menginternalisasikan (menanamkan dalam pribadi) nilai-nilai Islami, juga mengembangkan anak didik agar mampu mengamalkan nilai-nilai itu secara dinamis dan fleksibel dalam batas-batas konfigurasi idealitas wahyu Tuhan. Dalam arti, pendidikan agama 
Islam secara optimal harus mampu mendidik anak didik agar memiliki "kedewasaan atau kematangan" dalam berpikir, beriman, dan bertakwa kepada Allah SWT. Di samping itu juga mampu mengamalkan nilai-nilai yang mereka dapatkan dalam proses pendidikan, sehingga menjadi pemikir yang baik sekaligus pengamal ajaran Islam yang mampu berdialog dengan perkembangan kemajuan zaman.

Peran strategis PAI dalam sistem pendidikan nasional, utamanya dalam mengembangkan manusia Indonesia yang beriman, bertakwa kepada Tuhan yang maha Esa dan berbudi pekerti luhur, sebagai bagian essensial dalam pembangunan manusia Indonesia seutuhnya. Pendidikan karakter di perguruan tinggi juga menjadi sebuah tuntutan karena karakter tidak hanya mendemonstrasikan etika atau sistem nilai personal yang ideal (baik dan penting) untuk eksistensi diri dan berhubungan dengan orang lain, tetapi juga pendidikan karakterdapat dimaknai sebagai pendidikan nilai, pendidikan budi pekerti, pendidikan moral, pendidikan watak, yang bertujuan mengembangkan kemampuan peserta didik untuk memberikan keputusan baik-buruk, memelihara apa yang baik, mewujudkan dan menebar kebaikan itu dalam kehidupan sehari-hari dengan sepenuh hati. Hampir dalam setiap pembelajaran, guru dan peserta didik sering dihadapkan pada berbagai masalah, baik yang berkaitan dengan mata pelajaran maupun yang menyangkut hubungan sosial. Pemecahan masalah pembelajaran dapat dilakukan melalui berbagai cara, melalui diskusi kelas, tanya jawab antara guru dan peserta didik, penemuan dan inkuiri. Guru kreatif senantiasa mencari pendekatan-pendekatan baru dalam memecahkan masalah, tidak terpaku pada cara tertentu yang monoton, melainkan memilih variasi yang lebih tepat. Bermaian peran merupakan salah satu alternatif yang dapat ditempuh. Hasil penelitian dan percobaan yang dilakukan oleh para ahli menunjukan bahwa bermain peran merupakan salah satu model yang dapat digunakan secara efektif dalam pembelajaran. Dalam hal ini, bermain peran diarahkan pada pemecahanpemecahan masalah yang menyangkut hubungan antar manusia, terutama yang menyangkut kehidupan peserta didik.

Melalui bermain peran, para peserta didik mencoba mengeksplorasi hubunganhubungan antarmanusia dengan cara memperagakannya dan mendiskusikannya sehingga secara bersama-sama para peserta didik dapat mengeksplorasi perasaan-perasaan, sikapsikap, nilai-nilai, dan berbagai strategi pemecahan masalah. Sebagai suatu model pembelajaran berkarakter, bermain peran berakar pada dimensi pribadi sosial. Dari dimensi pribadi model ini berusaha membantu peserta didik menemukan makna dari lingkungan sosial bermanfaat bagi dirinya. Oleh karena itu , melalui model ini para peserta didik diajak untuk belajar memecahkan masalah-masalah pribadi yang sedang dihadapinya dengan bantuan kelompok sosial yang beranggotakan teman-teman sekelas. Dari dimensi sosial, model ini memberikan kesempatan kepada peserta didik untuk bekerja sama dalam menganalisis situasi-situasi sosial, terutama masalah yang menyangkut hubungan antar pribadi peserta didik. Pemecahan masalah tersebut dilakukan secara demokratis. Dengan demikian melalui model ini para peserta didik juga dilatih untuk menjunjung tinggi nilai-nilai demokratis.

Mata kuliah pendidikan agama islam di Sekolah Tinggi Keguruan dan Ilmu Pendidikan (STKIP) Banten mempunyai peranan yang sangat penting dan strategis, karena merupakan mata kuliah umum (MKU) yang wajib diikuti oleh semua mahasiswa baru pada strata satu (S-1). Mahasiswa dapat belajar dengan aktif, jika dosen dapat menciptakan dan memelihara kondisi belajar yang optimal. Di mulai dengan penggunaan media yang bervariasi, model pembelajaran yang tepat dan beragam juga tersedianya bahan ajar yang 
dapat mendukung kegiatan pembelajaran dan sarana dan prasarana yang memadai yang dapat mencapai hasil pembelajaran yang optimal.

Mata kuliah pendidikan agama Islam yang didapatkan mahasiswa dari dosen kadang tidak mencerminkan perkembangan pendekatan dengan yang mereka alami dalam kehidupan masyarakat, sehingga mata kuliah Pendidikan Agama Islam dirasakan tidak akomodatif terhadap teori-teori modern yang berkembang dalam realitas kehidupan. Muslih Usa menambahkan bahwa bagian lain kaitan organis dan fungsional sistem kehidupan modern juga melahirkan pertentangan yang amat berarti dengan apa yang diperoleh anak dari pendidikan agama di lembaga pendidikan, karena metode dan isi pelajaran agama kurang berhubungan dengan lingkungan yang dialaminya. Berbagai permasalahan tersebut di atas senada dengan pendapat Ahmad Lujito yang dikutip oleh Chabib Thoha, sebagai berikut: sungguhpun kedudukan PAI sebagai sub sistem dari sistem pendidikan nasional cukup kuat, dalam pelaksanaanya masih dijumpai beberapa masalah, antara lain: 1) kurangnya jumlah pelajaran, 2) metodologI PAI yang kurang tepat, 3) adanya dikotomi pendidikan agama dan pendidikan umum, 4) heterogenitas pengetahuan dan penghayatan agama peserta didik, dan 5) perhatian dan kepedulian pimpinan.

Abdul Majid dan Dian Andayani (2004) mengatakan kurikulum pendidikan Agama Islam berfungsi sebagai berikut: 1) pengembangan, yaitu meningkatkan keimanandan ketakwaan peserta didik kepada Allah SWT yang telah ditanamkan dalam lingkungan keluarga, 2) penanaman nilai sebagai pedoman hidup untuk mencari kebahagiaan hidup di dunia dan di akhirat, 3) penyesuaian mental, Yaitu untuk menyesuaikan diri dengan lingkungan nya baik fisik maupun lingkungan sosial dan dapat mengubah lingkunganya sesuai dengan ajaran islam, 4) perbaikan, yaitu memperbaiki kesalahan-kesalahan, kekurangan-kekurangan, dan kelemahan-kelemahan peserta didik dalam keyakinan pemahaman dan pengalaman ajaran dalam kehidupan sehari-hari, 5) pencegahan, yaitu untuk menangkal hal-hal negatif dari lingkungan nya atau dari budaya lain yang dapat membahayakan dirinya dan menghambat perkembangan menuju manusia Indonesia seutuhnya, 6) pengajaran tentang ilmu pengetahuan keagamaan secara umum, sistem dan fungsionalnya, 7) penyaluran, yaitu untuk menyalurkan anak-anak yang memiliki bakat khusus di bidang agama islam agar bakat tersebut dapat berkembang secara optimal sehingga dapat dimanfaatkan untuk dirinya sendiri serta bagi orang lain.

Penggunaan pendekatan sistem dalam pengembangan instruksional akan menghasilkan sebuah model untuk memecahkan masalah yang dihadapi dalam proses pembelajaran pendidikan agama islam. Dalam hal ini model yang di gunakan adalah model simulasi dalam pembelajaran PAI. Pencapaian suatu tujuan pembelajaran turut ditentukan oleh ketepatan penggunaan-penggunaan model pembelajaran, karena model yang dipilih oleh dosen diharapkan dapat mengoptimalkan aktifitas belajar mahasiswa.

Adapun tujuan penelitian ini adalah untuk mengembangkan model pembelajaran pendidikan agama islam dengan pendekatan simulasi di STKIP Banten. Karena luasnya cakupan cakupan materi Pendidikan Agama Islam, maka materi yang akan dikembangkan mengenai penyelenggaraan jenazah meliputi; memandikan jenazah, mengkafani jenazah, menshalatkan jenazah dan memakamkan jenazah.

\section{Metode Penelitian}

Penelitian ini menggunakan metode penelitian dan pengembangan Reserch and Development (R\&D). sebagaimana dikatakan W. R. Borg \& M. D. Gall, penelitian pendidikan dan pengembangan adalah suatu proses untuk mengembangkan dan memvalidasi 
produk-produk pendidikan. Sedangkan Sugiyono menyatakan bahwa, penelitian dan pengembangan adalah metode penelitian yang digunakan untuk menghasilkan produk tertentu dan menguji keefektifan produk tersebut. Menguji keefektifan produk dilakukan dengaan uji coba, orientasi kegiatan uji coba produk ini adalah untuk memperoleh sejumlah data dan informasi yang berfungsi sebagai bahan masukan terhadap perbaikan produk, sehingga bermuara pada suatu produk berupa model pembelajaran yang layak dan berkualitas untuk kegiatan pembelajaran.

Pada penelitian dan pengembangan ini, peneliti menggunakan langkah-langkah pendekatan penelitian dan pengembangan pendidikan yang dikemukakan oleh Borg dan Gall. Tahapan penelitian dan pengembangan Borg dan Gall terdiri dari: 1) penelitian dan pengumpulan data, 2) perencanaan, 3) pengembangan draft produk, 4) uji coba lapangan awal, 5) merevisi hasil uji coba, 6) uji coba lapangan , 7) penyempurnaan produk hasik uji coba lapangan, 8) uji pelaksanaan lapangan, 9) penyempurnaan produk akhir dan 10) desiminasi dan implementasi. Tahapan penelitian dan pengembangan pada model Borg dan Gall ini berhenti pada langkah ke delapan, sedangkan langkah kesembilan perbaikan hasil akhir, dan langkah kesepuluh penerapan dan desiminasi, tidak dilakukan karena keterbatasan kemampuan peneliti dan pertimbangan dari segi waktu yang akan dibutuhkan lebih lama, biaya yang digunakan cukup besar dan tenaga yang cukup besar. Penelitian ini dilakukan di Sekolah Tinggi Keguruan dan Ilmu Pendidikan Banten. Mengingat adanya keterbatasan waktu dan biaya, maka pengembangan ini dilakukan hanya sampai tahap uji coba lapangan utama.

Pengumpulan data dilakukan menggunakan instrument yang terdiri dari angket dan tes. angket digunakan dalam pengambilan data, terlebih dahulu dilakukan pengujian validitas konstruk dengan pendapat dari ahli (judgment expert). Setelah angket dikonstruksikan tentang aspek-aspek yang akan diukur dengan berlandaskan teori tertentu, maka selanjutnya dikonsultasikan dengan ahli. Para ahli diminta pendapatnya tentang instrument yang telah disusun itu. tes digunakan untuk pengambilan data penelitian, maka dilakukan uji coba. Tujuannya untuk mengetahui keshahihan (validitas), keajegan (reliabilitas) alat penelitian, dengan mengujikannya kepada mahasiwa di luar sampel. uji validitas tes dilakukan dengan menggunakan rumus Korelasi Point Biserial. Untuk menguji reliabilitas tes menggunakan rumus $K R-20$.

Teknik Analisis data yang digunakan adalah statistik deskriptif kualitatif. Statistik deskriptif kualitatif digunakan untuk menganalisa data dengan cara mendeskripsikan atau menggambarkan data yang telah terkumpul sebagaimana adanya tanpa bermaksud membuat kesimpulan yang berlaku untuk umum atau generalisasi. Angket yang diperoleh dari hasil validasi ahli materi, ahli desain instruksional, ahli media, uji coba satu-satu, uji coba kelompok kecil dan uji coba lapangan, dianalisa dengan cara menghitung nilai berdasarkan skala penilaian. Data yang diperoleh dari tes, dianalisis dengan membandingkan nilai pretes dan posttest mahasiswa dari ranah kognitif maupun psikomotorik.

\section{Hasil Penelitian dan Pembahasan}

Penelitian dan pengembangan ini adalah menghasilkan model pembelajaran simulasi pada mata kuliah Pendidikan Agama Islam untuk mahasiswa STKIP Banten. Model pembelajaran yang dikembangkan ini digunakan oleh mahasiswa dan dosen PAI (STKIP) Banten dalam rangka memudahkan pelaksanaan simulasi untuk materi yang bermuatan praktek. 
Langkah awal dalam pengembangan model pembelajaran ini adalah membuat desain pembelajaran. Dari langkah ini dihasilkan sebuah desain pembelajaran untuk mata kuliah pendidikan agama Islam. Analisis desain pembelajaran ini dimulai dari merumuskan tujuan umum, merumuskan tujuan khusus, mengembangkan instrument penilaian, mengembangkan strategi instruksional dan mengembangkan materi/bahan ajar. Berdasarkan analisis ini, maka dikembangkan (1) silabus pembelajaran, (2) Satuan Acara Perkuliahaan (SAP) (3) menyusun bahan ajar, (4) alat evaluasi. Silabus pembelajaran terdiri dari satu standar kompetensi dan empat kompetensi dasar. SAP terdiri dari empat pertemuan pembelajaran yang dikembangkan dari empat kompetensi dasar. Untuk materi/bahan ajar berasal dari berbagai sumber seperti dari modul pembelajaran yang sudah ada, internet dan juga power point. Modul dibuat dalam bentuk media cetak (hard copy) yaitu satu paket pembelajaran simulasi. Setelah desain pembelajaran dilakukan, maka tahap berikutnya adalah membuat desain produk model pembelajaran dengan membuat flowchart yang berisikan desain tampilan model pembelajaran, gambar, ilustrasi dan narasi dari model pembelajaran yang dikembangkan.

Langkah selanjutnya, pelaksanaan produksi model pembelajaran simulasi. Terlebih dahulu menginstal software yang dibutuhkan diantaranya Adobe Flash CS3, Adobe Photoshof CS3. Setelah itu dilakukan dengan pembuatan image dan logo untuk tampilan cover paket pembelajaran simulasi dengan warna dasar hijau, melakukan pemilihan layout, pembuatan tombol dan pengisian content pada paket pembelajaran meliputi petunjuk penggunaan paket pembelajaran simulasi, membuat analisis instruksional, membuat strategi pembelajaran, pengisian materi, skenario simulasi, latihan/evaluasi serta penambahan fitur-fitur lainnya.

Hasil penelitian pendahuluan diperoleh dengan menyebarkan angket kepada 30 orang mahasiswa PAI. Dari angket diperoleh data bahwa mahasiswa sebanyak 25 mahasiswa $(83,3 \%)$ menyatakan kurang memahami dan mengaplikasian materi yang bermuatan praktek, sebanyak 3 mahasiswa (10\%) menyatakan cukup memahami dan dapat mempraktekannya, dan 2 mahasiswa (6,6\%)menyatakan sangat memahami dan dan dapat mengaplikasikannya. Penyebab materi pembelajaran sulit dipahami menurut 23 mahasiswa $(76,6 \%)$ karena belum menggunakan model pembelajaran yang tepat, sebanyak 5 mahasiswa $(16,6 \%)$ menyatakan kurang visualisasi aplikasi dari materi yang diajarkan, sebanyak 3 mahasiswa (10\%) menyatakan cara penyampaian dosen kurang jelas. Dari sumber belajar diperoleh data bahwa sumber belajar yang ada dikampus belum mencukupi, ini dapat dilihat dari hasil angket sebanyak 30 mahasiswa (100\%) menyatakan perlu adanya sumber belajar yag beragam pada proses pembelajaran

Dari wawancara informal dengan dosen diketahui bahwa dalam proses pembelajaran PAI belum menggunakan model pembelajaran yang berfariasi sehingga pada materi-materi yang bermuatan praktek tertentu sulit untuk melakukan praktek langsung. Dikarenakan sarana prasarana yang kurang memadai dan tidak tersedianya sumber belajar yang menunjang proses pembelajaran. Modul perkuliahaan yang dimiliki mahasiswa kurang dimanfaatkan dengan baik karena mahasiswa malas membacanya. Nilai yang didapatkan mahasiswa mununjukan kategori cukup baik yaitu pada kisaran 70-80 pada rentang interval 0-100, namun nilai tersebut belum optimal. Selain itu adanya kecenderungan dalam pembelajaran mata kuliah praktek, bahasan dan teori yang mengiringi pembelajaran kurang mendapat perhatian yang semestinya.Dari data yang diperoleh pada penelitian pendahulan mendorong peneliti untuk mengembangkan model pembelajaran PAI, melalui penyajian model dalam bentuk simulasi, akan dapat membuat pembelajaran lebih menarik dan mahasiswa akan lebih 
mudah faham karena mahasiswa mengalami langsung tidak hanya teori khususnya untuk materi-materi yang bermuatan praktek.

\section{Kelayakan Model}

Penelitian ini menggunakan dua tahapan utama dalam menguji kelayakan produk yaitu validasi teori dan validitas empirik. Validitas teoritik didapat atas validasi dan evaluasi oleh para ahli (expert judgment) untuk menilai kelayakan model pembelajaran yang dikembangkan. Penilaian ini akan menjadi dasar untuk memperbaiki model yang dinilai kurang baik oleh para ahli yang diminta menilai model pembelajaran ini adalah mereka yang memiliki latar belakang keahlian dalam bidang media pembelajaran, desain pembelajaran dan materi Pendididkan Agama Islam.

Para ahli yang menilai dalam penelitian model pembelajaran pendidikan agama islam dengan pendekatan simulasi ini adalah ahli desain pembelajaran yang menilai aspek pembelajaran dengan mendapatkan skor rata-rata 3.06 yang berarti program ini dinilai baik. Ahli materi yaitu menilai komponen materi dengan mendapatkan skor rata-rata 3.4 yang berarti pengembangan model pembelajaran ini dinilai baik. Kemudian ahli media yang menilai komponen tampilan dengan mendapatkan skor rata-rata 3.17 yang berarti program ini dinilai baik. Validitas Empirik dilakukan dengan uji coba satu-satu, Uji coba ini dimaksudkan untuk mengetahui kelayakan model pembelajaran secara empirik, uji coba dilakukan terhadap 3 orang teman sejawat. Pengembang meminta teman sejawat untuk memberikan komentar dengan leluasa tentang model pembelajaran. Pada tahap ini responden diminta untuk mencatat, mengamati, mencermati dan mendiskusikan program pembelajaran yang sedang mereka pelajari. Evaluasi dilakukan dengan dua cara yaitu melalui penyebaran angket dan wawancara satu persatu. Ada tiga komponen yang akan dievaluasi oleh teman sejawat yaitu komponen pembelajaran, komponen materi dan komponen tampilan Hasil evaluasi satu persatu orang (one to one) diperoleh data sebagai berikut:

Tabel 1. Hasil Penilaian Uji Coba One to One

\begin{tabular}{|c|l|c|}
\hline No & \multicolumn{1}{|c|}{ Komponen } & Rata-rata \\
\hline A & Komponen Pembelajaran & 3.0 \\
B & Komponen Materi & 3.0 \\
C & Komponen Tampilan & 3.27 \\
\hline & Rata- rata keseluruhan & $\mathbf{3 . 0 9}$ \\
\hline
\end{tabular}

Terkait dengan komponen pembelajaran secara keseluruhan, skor rata-rata yang didapatkan 3.0, nilai tersebut pada kategori baik. Berdasarkan informasi dari wawancara untuk kejelasan rumusan kompetensi, peserta dapat menangkap dengan baik maksud dari indikator pembelajaran. Artinya kejelasan indikator kejelasan indicator pembelajaran menjadi rujukan peserta dalam mempelajari materi dan mengikuti kegiatan pembelajaran.

Aspek isi/materi, secara keseluruhan mendapatkan skor rata-rata 3.0, nilai ini juga berada pada kategori baik. Indicator mengenai kesesuaian judul dengan isi paket pembelajaran mendapatkan skor rata-rata 3.0. Pendapat peserta mengenai kesesuaian materi dengan judul dapat dikatakan sudah sesuai, mengenai kejelasan uraian materi secara umum sudah jelas, terdapat peserta yang berpendapat, selaian uraian materi secara rinci sebaiknya materi yang 
disajikan dikemas dalam bentuk point-point sehingga memudahkan peserta dalam menangkap maksud dari uraian tersebut. Mengenai kesesuaian materi dengan kemampuan peserta, mereka berpendapat materi yang disajikan dapat mereka ikuti dengan baik, dan sesuai dengan kebutuhan mereka yang bias dikatakan sama sekali belum mengetahui tentang materi yang disajikan.

Sedangkan untuk komponen tampilan masing-masing mendapatkan skor rata-rata 3.27. penilaian ini dapat dikategorikan baik. Menyangkut penggunaan gambar, simbol dan teks, peserta berpendapat gambar dan simbol yang digunakan menarik, sedangkan teks yang digunakan cukup menarik. Menyangkut dengan layout paket pembelajaran, menyangkut tulisan dan jenis huruf yang digunakan peserta berpendapat bahwa jenis dan ukuran huruf jelas. Pada uji coba satu-satu ini mendapatkan masukan dari peserta/responden mengenai tulisan karena dalam penggunaan tanda baca dan penggunaan ejaan masih banyak kesalahan. Berdasarkan wawancara dengan peserta secara keseluruhan menyatakan bahwa paket pembelajaran ini menarik dan mudah dipahami dalam pembelajaran.

Setelah uji coba satu-satu maka dilakuakn uji coba kelompok kecil. Evaluasi kelompok kecil bertujuan untuk mendapatkan informasi yang digunakan untuk menyempurnakan produk dalam revisi berikutnya. Tahap evaluasi dilakukaun oleh 6 orang mahasiswa STKIP Banten semester satu. Tahap evaluasi dimulai dengan memberikan angket kepada responden, kemudian responden bersama-sama pengembang bersama-sama melihat produk. Pada tahap ini responden diberi waktu dua sampai tiga hari untuk mencermati produk. Ada tiga komponen yang akan dievaluasi oleh responden yaitu, komponen pembelajaran, komponen materi dan komponen tampilan. Hasil evaluasi kelompok kecil diperoleh data sebagai berikut:

Tabel 1. Hasil Penilaian Uji Coba Kelompok Kecil

\begin{tabular}{|c|l|c|}
\hline No & \multicolumn{1}{|c|}{ Komponen } & Rata-rata \\
\hline A & Komponen Pembelajaran & 3.3 \\
\hline B & Komponen Materi & 3.3 \\
\hline C & Komponen Tampilan & 3.2 \\
\hline & Rata- rata keseluruhan & $\mathbf{3 . 3}$ \\
\hline
\end{tabular}

Data dari masing-masing komponen yang diujicobakan penilaian yang didapat dari responden dapat diuraikan sebagai berikut:

Terkait komponen pembelajaran secara keseluruhan, skor rata-rata yang didapatkan 3.3, nilai tersebut berada pada kategori baik. Dengan mengkaji data yang terkumpul melalui angket diatas, pencapaian skor rata-rata mengalami peningkatan dibandingkan dengan evaluasi satu-satu. Kesimpulan dari hasil wawancara, mengenai kejelasan rumusan tujuan pembelajaran, rata-rata mahasiswa memahami maksud dari tujuan rumusan tujuan yang dinyatakan dalam pembelajaran dengan kata lain mereka paham mengenai kemampuan apa yang harus mereka dapatkan setelah mereka menyelesaikan materi pembelajaran. Pada komponen materi, secara keseluruhan mendapatkan skor rata-rata 3.3, nilai ini juga berada pada kategori baik. Pendapat mahasiswa mengenai kesesuaian materi dengan judul dapat dikatakan sudah sesuai, sedangkan mengenai kesesuaian materi dengan kemampuan peserta, mereka berpendapat materi yang disajikan dapat mereka ikuti dengan baik, setiap inti bahasan materi dapat mereka pahami dengan baik. Karena sebelumnya sudah dilakukan revisi terhadap uraian materi berdasarkan saran pada waktu uji coba satu-satu. Evaluasi dinilai 
sudah sesuai dengan indicator pembelajaran yang terdapat pada materi PAI. Pertanyaan pada evaluasi sudah jelas karena mahasiswa dapat memahami maksud pertanyaan.

Komponen tampilan masing-masing mendapatkan skor rata-rata 3.2. penilaian ini dapat dikategorikan baik. Gambar dan teks yang digunakan dinilai menarik minat mahasiswa karena disertai ilustari di setiap tahapan-tahapan yang akan di paraktekan. Karena itu dapat menarik minat mahasiswa untuk terus mempelajari ke materi selanjutnya atupun mengulangi kembali mengerjakan latihan tersebut. Menurut mahasiswa dengan adanya petunjuk penggunaan dan arahan sangat membantu mereka dalam menggunakan model pembelajaran karena mereka belum pernah menggunakan model pembelajaran simulasi khusunya untuk materi yang bermuatan praktek. Mengenai bahasa yang digunakan sudah sesuai dengan tingkatan pendidikan mahasiswa.

Selanjutnya dilakukan evaluasi lapangan utama, Uji coba lapangan bertujuan untuk menggali informasi dan masukan dari mahasiswa mengenai model pembelajaran dan juga menekankan pada kejelasan dan keefektifan setiap komponen pada model pembelajaran, yaitu komponen pembelajaran, komponen materi dan komponen tampilan. Uji coba dilakukan oleh 30 orang mahasiswa PAI semester 1 STKIP Banten. Uji coba dilakukan dikelas, kemudian mahasiswa membaca paket pembelajaran simulasi selama 1 jam, kemudian angket diberikan kepada responden untuk diisi. Setelah terkumpul dapat diketahui data pada beberapa komponen yaitu; komponen pembelajaran, komponen materi dan komponen tampilan. Berikut data hasil evaluasi utama: Data yang diperoleh melalui penyebaran angket pada uji coba lapangan dapat digambarkan sebagai berikut:

Tabel 1. Hasil Penilaian Uji Coba Lapangan

\begin{tabular}{|l|l|c|}
\hline No & \multicolumn{1}{|c|}{ Komponen } & Rata-rata \\
\hline A & Komponen Pembelajaran & 3.5 \\
B & Komponen Materi & 3.6 \\
C & Komponen Tampilan & 3.6 \\
\hline & Rata- rata keseluruhan & $\mathbf{3 . 6}$ \\
\hline
\end{tabular}

Table di atas menunjukkan secara umum pada tahap uji coba lapangan diperoleh hasil bahwa model pembelajaran yang dikembangkan dapat dikatakan baik dengan rata-rata nilai keseluruhan 3.6 hal ini menunjukan peningkatan dari hasil penialian sebelumnya. Komponen materi, secara keseluruhan mendapatkan skor rata-rata 3.6, nilai ini juga berada pada kategori baikk. Sedangkan untuk komponen tampilan masing-masing mendapatkan skor rata-rata 3.6. penilaian ini dapat dikategorikan baik. Mengenai unsur relevansi materi dengan tujuan pembelajaran secara keseluruhan mereka menggagap sangat relevan dengan pembelajaran, khususnya dalam pembelajaran pendidikan agama islam yang bermuatan praktek. Menurut mahasiswa, petunjuk penggunaan dan arahan sangan membantu mereka dalam menggunakan model pembelajaran simulasi. mengenai bahasa yang digunakan sudah sesuai. Evaluasi dinilai sudah sesuai dengan indicator pembelajaran yang terdapat pada materi pendidikan agama islam. Pernyataan pada evaluasi sudah jelas. Penggunaan simbol dan ilustrasi juga dinilai sudah jelas dalam setiap langkah-langkah pelaksanaan simulasi. 


\section{Hasil UJI Coba Efektifitas Model Pembelajaran PAI dengan Pendekatan Simulasi}

Uji coba lapangan dilakukan untuk mengetahui efektifitas model pembelajaran pendidikan agama islam dengan pendekatan simulasi yang dikembangkan. Efektifitas diukur dengan angket untuk mendapatkan pendapat mahasiswa mengenai model pembelajaran PAI dan menganalisis hasil belajar (pretest dan post test) pada ranah kognitif dan psikomotorik dengan menetapkan skor minimum pencapai kompetensi sebesar 75 (tujuh puluh lima)

Uji coba dilakukan terhadap 30 orang mahasiswa yang belum mendapatkan materi PAI tentang penyelenggaraan jenazah. Uji coba dilakukan melalui langkah-langkah berikut: sebelum diberi penjelasan mengenai pembelajaran PAI dengan menggunakan model simulasi, mahasiswa diberikan pretes. Mahasiswa diminta untuk menjawab beberapa pertanyaan yang ada pada lembar soal. Hasil dari pretes mengidentifikasi bahwa materi pelajaran benar-benar dibutuhkan oleh mahasiswa untuk menambah pemahaman dan pengetahuan khususnya untuk materi yang bermuatan praktek dalam hal ini yaitu tentang penyelenggaraan jenazah. Informasi ini dapat disimpulkan dari skor yang didapatkan oleh 30 orang mahasiswa yang mengikuti pretes untuk menilai ranah kognitif ini, mereka mendapatkan skor rata-rata 66.91 dari 100 skor tertinggi. Pencapaian angka ini dapat dikategorikan rendah.

Mahasiswa diberikan waktu selama 4 kali pertemuan masing-masing 30 menit untuk mempelajari setiap pokok bahasan yang terdapat pada model pembelajaran dan mengerjakan soal latihan. Pada pertemuan ke 4, mahaiswa harus sudah mempelajari semua pokok bahasan dan latihan yang ada pada setiap pertemuan. Mahasiswa diminta mengerjakan posttest untuk menilai ranah kognitif didapatkan skor rata-rata 77,66. dan hasil psikomotorik didapatkan skor rata-rata 3.8 pencapaian angka ini dapat dikategorikan baik dan menunjukan terdapat peningkatan hasil belajar setelah menggunakan model simulasi pada pembelajaran pendidikan agama islam. Mahasiswa mengapresiasi pembelajaran dengan menggunakan model simulasi karena sangat menambah wawasan pengetahuan, memotivasi dan mudah di pahami dalam pembelajaran.

\section{Pembahasan Pengembangan Model Pembelajaran Pendidikan Agama Islam dengan Pendekatan Simulasi.}

Faktor Pendukung: Program ini dibuat dengan Software Adobe Flash sehingga tampilan terlihat lebih menarik, ilustrasi menarik dan menggunakan visualisasi yang sesuai,Evaluasi dan latihan yang interaktif dan sesuai dengan karakteristik materi dan Program ini dapat dijadikan sebagai sumber belajar.

Faktor Penghambat:Terlalu banyak dan kompleksnya materi Pendidikan agama islam yang bermuatan praktek, Hanya dilakukan pada satu kelas yang menjadi sasaran utama penelitian, kemudian dibandingkan dengan kelas lain yang tidak menggunakan model pembelajaran simulasi untuk materi yang bermuatan praktek, Terbatasnya fasilitas yang dimiliki peneliti untuk mengembangkan produk, Proses evaluasi dan dan revisi fokus pada program model pembelajaran simulasi. sementara perangkat pembelajaran yang lain, kurang intens, hal ini menjadi kelemahan lain dari model pembelajaran ini, karena untuk perangkat mulai dari silabus, SAP, dan evaluasi. Proses evaluasi dan revisinya hanya sampai pada kaji ahli, tidak sampai pada uji coba baik satu-satu maupun lapangan.

\section{Kesimpulan dan Saran}

Hasil penelitian ini dapat disimpulkan bahwa pengembangan model pembelajaran PAI dengan pendekatan simulasi telah diselesaikan dengan menggunakan validasi beberapa tahap. Proses desain adalah langkah awal memulai pengembangan, yaitu pengumpulan data, 
sasaran, materi dan komponen penunjang lainnya. Proses kedua adalah produksi, proses ini merupakan proses bahwa semua yang telah dikumpulkan disusun dalam sebuah produk awal. Proses berikutnya adalah evaluasi oleh ahli materi, ahli media, ahli materi, ahli desain instruksional, uji coba one to one, uji coba kelompok kecil dan uji coba lapangan. Dari hasil evaluasi ahli materi, ahli media dan ahli desain instruksional masing-masing memberikan masukan untuk memperbaiki model pembelajaran. Hasil penilaian oleh ahli materi memberikan skor 3.4, ahli desain pembelajaran memberikan skor 3.06 dan ahli media memberikan skor 3.17 yang menunjukan model pembelajaran pendidikan agama islam dinilai baik. Pada uji coba one to one dengan melibatkan 3 orang teman sejawat didapatkan skor 3.09 yang menunjukan model pembelajaran pendidikan agama islam dinilai baik. Pada uji coba kelompok kecil dengan melibatkan 8 orang mahasiswa didapatkan skor 3.3 yang menunjukan model pembelajaran pendidikan agama islam dinilai baik. Pada uji coba lapangan dengan melibatkan 30 orang mahasiswa didapatkan skor 3.6 yang menunjukan model pembelajaran pendidikan agama islam dinilai baik. Selain itu rerata nilai pretest dan posttest pada ranah kognitip masing-masing mendapatkan nilai 66.91 dan 77.66 . pada rerata nilai ranah psikomotorik didapatkan skor 3.8. secara umum model pembelajaran pendidikan agama islam dengan pendekatan simulasi yang dihasilkan dinilai baik untuk pembelajaran dan dapat menambah wawasan mahasiswa.

\section{Daftar Pustaka}

Abdul Majid dan Dian Handayani. (2004). Pendidikan Agama Islam Berbasis Kompetensi Konsep Dan Implementasi Kurikulum. Bandung: PT. Remaja Rosdakarya.

Asmuni, A. (2020). Penerapan Model Pembelajaran Learning Cycle 5e untuk Meningkatkan Aktivitas dan Penguasaan Konsep Siswa Pada Mata Pelajaran PAI dan Budi Pekerti di SMA Negeri 1 Selong. Jurnal Paedagogy, 7(3), 175-185. doi:https://doi.org/10.33394/jp.v7i3.2743

Atwi Suparman. (2010). Desain Instruksional . Jakarta : Penerbit Universitas Terbuka

Abdurrahman An Nahlawi. (1995). Ushuluut Tarbiyyah Iskamiyyah wa Asalibiha fil Baiti wal Madrasati wal Mujtama' diterjemahkan oleh Shibabuddin. Jakarta: Gema Insani Press

Achmadi. (1992). Islam Sebagai Paradigma Ilmu Pendidikan .Yogyakarta: Aditya Media.

Ahmad Munjin Nasih, Lilik Nur Kholifah. (2009). Metode dan Tekhnik Pembelajaran Pendidikan Agama Islam. Refika Aditama

Bambang Warsita. (2008) Teknologi Pembelajaran, Landasan dan Aplikasinya: Jakarta: Rineka Cipta

Dewi salma Prawiradilaga. (2009). Prinsip Desain Pembelajaran. Jakarta: Kencana

Eveline Siregar dan Hartini Nara. (2010). Teori Belajar dan Pembelajaran . Bogor : Penerbit Ghalia Indonesia

E. Mulyasa. (2011). Manajemen pendidikan karakter. Jakarta: PT Bumi Aksara

Hamzah B.Uno, Iffah Budiningsih, Keysar Panjaitan. (2004). Model Pembelajaran. Gorontalo: Nurul Jannah

Hamzah B. Uno. (2011). Model Pembelajaran, Menciptakan Proses Belajar Mengajar yang Kreatif dan Efektif. Jakarta : PT. Bumi Aksara.

Purnawan, D., \& Astutik, F. (2019). PENGARUH PENGGUNAAN SIMULASI JARINGAN KOMPUTER CISCO PACKET TRACER TERHADAP KREATIVITAS BELAJAR SISWA. Jurnal Teknologi Pendidikan, O(2), 21-31. Retrieved from http://ojs.ikipmataram.ac.id/index.php/jtp/article/view/1236 